\title{
NERVE GROWTH FACTOR-MEDIATED INDUCTION OF CHOLINE ACETYLTRANSFERASE IN PC12 CELLS: EVALUATION OF THE SITE OF ACTION OF NERVE GROWTH FACTOR AND THE INVOLVEMENT OF LYSOSOMAL DEGRADATION PRODUCTS OF NERVE GROWTH FACTOR $^{1}$
}

\author{
ROLF HEUMANN,"2 MARTIN SCHWAB, RAINER MERKL, AND HANS THOENEN
}

Max-Planck-Institute for Psychiatry, Department of Neurochemistry, and "Max-Planck-Institute for Biochemistry, Department of Cell Biology, D-8033 Martinsried, Federal Republic of Germany

Received January 23, 1984; Revised May 25, 1984; Accepted May 30, 1984

\begin{abstract}
In previous experiments it has been demonstrated that nerve growth factor (NGF), subsequent to its binding to specific membrane receptors, is internalized. Ultrastructurally, this internalized NGF is localized in membrane-confined compartments which ultimately fuse with lysosomes. The present experiments were designed, first, to evaluate whether a very small but functionally important portion of the internalized NGF might reach the free cytoplasm (and subsequently the nuclear chromatin) and might be responsible for the induction of choline acetyltransferase (ChAT) in PC12 cells. Second, we investigated whether a lysosomal proteolytic degradation product of NGF might act as a second messenger in the NGF-mediated ChAT induction. In one series of experiments, guinea pig erythrocyte ghosts, loaded with NGF (or NGF antibodies), fluorescein isothiocyanate-coupled bovine serum albumin, and/or horseradish peroxidase (HRP) were fused with PC12 pheochromocytoma cells. Electron microscopy showed that $\left[{ }^{125} \mathrm{I}\right] \mathrm{NGF}$ and $\mathrm{HRP}$ reaction product were located throughout the cytoplasm and the nucleus but did not penetrate membrane compartments such as the endoplasmic reticulum, the Golgi complex, the perinuclear space, or mitochondria. Biochemically, NGF injected into the cytoplasm did not produce an induction of ChAT, whereas NGF acting via cell surface receptors resulted in a 2 -fold increase in ChAT. Conversely, injection of NGF antibodies did not prevent the receptormediated ChAT induction.

In a second series of experiments, the half-life of internalized NGF was increased from 40 min to 24 hr by the administration of leupeptin, a protease inhibitor which is accumulated in lysosomes. However, the NGFmediated ChAT induction was not affected by this treatment. It is concluded that NGF itself does not act directly on cytoplasmic or nuclear target sites, nor is a proteolytic degradation product of NGF responsible for the NGF-mediated ChAT induction. Thus, NGF must act via a second messenger mechanism, the nature of which remains to be established.
\end{abstract}

Although the physiological importance of nerve growth factor (NGF) for the development and maintenance of function of the peripheral sympathetic and sensory nervous system is well established, the molecular mechanisms involved in the response are virtually unknown (T'hoenen and Barde, 1980, Yankner and Shooter, 1982; Bradshaw, 1983). The interaction of NGF with its receptors in many target cells has been analyzed (Banerjee et al., 1973; Costrini and Bradshaw, 1979; Shooter et al., 1981; Puma et al., 1983), but the sequence of events following the binding to its receptors which leads to multiple shortand long-term effects is largely unknown. Even the site of action of NGF is still a matter of debate, i.e., whether NGF acts directly on cytoskeletal elements and nuclear chromatin

\footnotetext{
${ }^{1}$ We thank Ms. M. Reitmayer and Ms. C. Müller for their excellent technical assistance, Dr. A. Acheson for critical review, and Ms. E. Eichler for typing the manuscript.

${ }^{2}$ To whom correspondence should be addressed.
}

(Calissano and Cozzari, 1974; Andres et al., 1977; Marchisio et al., 1980; Bradshaw, 1983) or via a second messenger mechanism(s) (Thoenen and Barde, 1980; Heumann et al., 1981).

Electron microscopic studies using either coupling products of NGF and horseradish peroxidase (HRP) or autoradiographic localization of ${ }^{125}$ I-labeled NGF did not provide any evidence that NGF, after selective receptor-mediated uptake into membrane-confined compartments, reaches the free cytoplasm and subsequently the nucleus (Schwab, 1977; Schwab and Thoenen, 1977; Claude et al., 1982). However, these investigations could not exclude the possibility that a very small amount of NGF (beyond the level of resolution and sensitivity of these methods) leaves the intracellular membrane-confined compartments and is responsible at least for part of the biological effects of NGF. This would be analogous to the action of diphtheria toxin (Pappenheimer, 1977), where a few molecules of the toxic subunit reaching the free cytoplasm are sufficient to block the protein synthesis of the target cells (Yamaizumi et al., 1978). To evaluate this question, we bypassed the cell surface NGF 
receptors and injected NGF or monospecific antibodies to NGF directly into the cytoplasm of $\mathrm{PC} 12$ pheochromocytoma tumor cells. These cells respond to NGF with a number of different responses such as immediate local effects on growth cones (Seeley and Greene, 1983), formation of neurites (Greene and Tischler, 1976), or induction of enzymes, for example, choline acetyltransferase (ChAT) (Edgar and Thoenen, 1978), acetylcholinesterase (Greene and Rukenstein, 1981; Lucas et al., 1981), and ornithine decarboxylase (Greene and McGuire, 1978; Hatanaka et al., 1978). After we had shown that fiber outgrowth is not influenced by free cytoplasmic NGF (Heumann et al., 1981), a finding that has been confirmed very recently (Seeley et al., 1983), it seemed to be important to establish whether a distinctly different but also characteristic response of PC12 cells to NGF, namely, the induction of ChAT, depends on the interaction of NGF with free cytoplasmic binding sites. Moreover, in order to evaluate whether a degradation product of NGF might be involved in the NGF-mediated ChAT induction and/or fiber outgrowth, we also studied the effect of impairing lysosomal degradation of NGF by leupeptin.

In agreement with previous experiments addressed to NGFmediated fiber outgrowth, the present experiments have demonstrated that NGF injected into the cytoplasm (and subsequently also reaching the nuclear chromatin) cannot mimic the NGF receptor-mediated ChAT induction. Conversely, monospecific NGF antibodies injected into the cytoplasm could not block the receptor-mediated induction of ChAT by NGF. The blockade of the lysosomal degradation of internalized NGF by leupeptin influenced neither ChAT induction nor fiber outgrowth.

\section{Materials and Methods}

\section{Materials}

NGF was purified from male mouse salivary glands according to the method of Bocchini and Angeletti (1969) as modified by Suda et al. (1978). Antiserum against NGF was raised in sheep, and NGF-specific antibodies were purified by affinity chromatography as described by Stoeckel et al. (1976). Other reagents, where not specified, were obtained from Sigma Chemical Co., Munich, Federal Republic of Germany. Guinea pig erythrocytes were obtained by heart puncture. Two milliliters of blood were suspended in $13 \mathrm{ml}$ of $0.1 \mathrm{M}$ sodium citrate buffer, centrifuged at $300 \times g$ for $5 \mathrm{~min}$, and resuspended in $0.3 \mathrm{M} \mathrm{Ca} /$ $\mathrm{Mg}$-free phosphate-buffered saline (CMF-PBS). The erythrocytes were washed again three times and stored for up to 4 weeks in the same buffer.

\section{Cell culture}

A subline of $\mathrm{PC} 12$ pheochromocytoma cells (fast reacting PC12 cells, PC12-FR), selected for fast and intense response to NGF with respect to fiber outgrowth and ChAT induction, was used for all experiments. Cells were cultivated in plastic tissue culture dishes (Falcon, BectonDickinson; Heidelberg, Federal Republic of Germany) in Dulbecco's modified Eagle's medium (DMEM) containing 10\% horse serum and $5 \%$ fetal calf serum (Gibco, Karlsruhe, Federal Republic of Germany).

\section{Loading of erythrocyte ghosts}

The loading of ghosts with NGF or affinity-purified NGF antibodies was performed according to the method of Yamaizumi et al. (1978) as modified by Heumann et al. (1981). Briefly, guinea pig erythrocytes were equilibrated in 0.5 to $1 \mathrm{ml}$ of "loading solution" (reverse PBS: 137

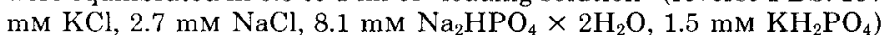
containing $20 \mathrm{mg} / \mathrm{ml}$ of fluorescein isothiocyanate (FITC)-labeled bovine serum albumin (BSA) and $44 \mu \mathrm{g} / \mathrm{ml}$ of NGF, cytochrome $c$, or 400 $\mu \mathrm{g} / \mathrm{ml}$ of affinity-purified NGF antibodies. In some experiments, 0.6 $\mathrm{mg} / \mathrm{ml}$ of horseradish proxidase (HRP, type VI) was included. For electron microscopic autoradiographic experiments or for degradation studies, ghosts were loaded with [ $\left.{ }^{125} \mathrm{I}\right] \mathrm{NGF}$ (lactoperoxidase labeling; specific activity, 50 to $60 \mu \mathrm{Ci} / \mu \mathrm{g}$ ). The loading efficiency (concentration of NGF in the ghosts as compared to the loading solution) was $100 \%$ for NGF but only $30 \%$ for NGF antibodies. Swelling and resealing of ghosts was performed by dialysis against $600 \mathrm{ml}$ of dilute (1:6) reverse
PBS for $30 \mathrm{~min}$ followed by $600 \mathrm{ml}$ of PBS for $30 \mathrm{~min}$ at room temperature. Ghosts were then centrifuged at $800 \times g$ for 5 min and resuspended in CMF-PBS. The washings were repeated two to three times. The biological activity of NGF or NGF antibodies within the ghosts was tested in a bioassay after lysis of the ghosts.

\section{Fusion of ghosts with PC12 cells}

The fusion procedure was similar to that described by Schlegel and Mercer (1980). PC12-FR cells $\left(1.5 \times 10^{6}\right)$ subcultured the day before fusion on polyornithine-treated plates ( $8.5 \mathrm{~cm}$ in diameter), were washed with CMF-PBS and incubated briefly (15 to $30 \mathrm{sec}$ ) with 150 $\mu \mathrm{g} / \mathrm{ml}$ of phytohemagglutinin type $\mathrm{P}$ (Serva, Heidelberg, Federal Republic of Germany) followed by incubation with $0.5 \mathrm{ml}$ of the loaded ghost suspension (containing $2.6 \times 10^{7}$ ghosts) for 3 to 6 min at $37^{\circ} \mathrm{C}$. Thereafter, an additional $0.3 \mathrm{ml}$ of the same ghost suspension was added and the cultures were kept at $37^{\circ} \mathrm{C}$ until the ghosts had attached to the cells ( 3 to $5 \mathrm{~min}$ ). After careful washing with CMF-PBS, plates were cooled to $4^{\circ} \mathrm{C}$ and fusion was initiated by addition of $1 \mathrm{ml}$ of $45 \%$ $(\mathrm{w} / \mathrm{v})$ polyethylene glycol 6000 (Roth, Karlsruhe, Federal Republic of Germany) in CMF-PBS. After an incubation time of $5 \mathrm{~min}$ at $4^{\circ} \mathrm{C}$, the fusion was terminated by addition of DMEM. The medium was changed to normal serum-containing medium after 15 to $30 \min \left(37^{\circ} \mathrm{C}\right)$. Two or $4 \mathrm{hr}$ later, the cells were washed with CMF-PBS and incubated with trypsin $(0.5 \%)$ in CMF-PBS for $10 \mathrm{~min}$ at $37^{\circ} \mathrm{C}$ in order to remove all of the non-fused ghosts. The fusion frequency was determined by fluorescence microscopy. The cell suspensions were then replated or subjected to fluorescence-activated cell sorting in a fluorescence-activated cell sorter (FACS) (see below).

\section{Cell sorting}

A FACS (FACS 4, Becton-Dickingson, Sunnyvale, CA) was used at an excitation wavelength of $488 \mathrm{~nm}$ and a flow rate of 700 to 800 cells/ sec (orifice, $80 \mu \mathrm{m}$ ). The frequency of ghost-injected fluorescent cells in the enriched fraction was 50 to $80 \%$ as compared to 25 to $35 \%$ before sorting. The sorted (injected and noninjected) cells were replated at a
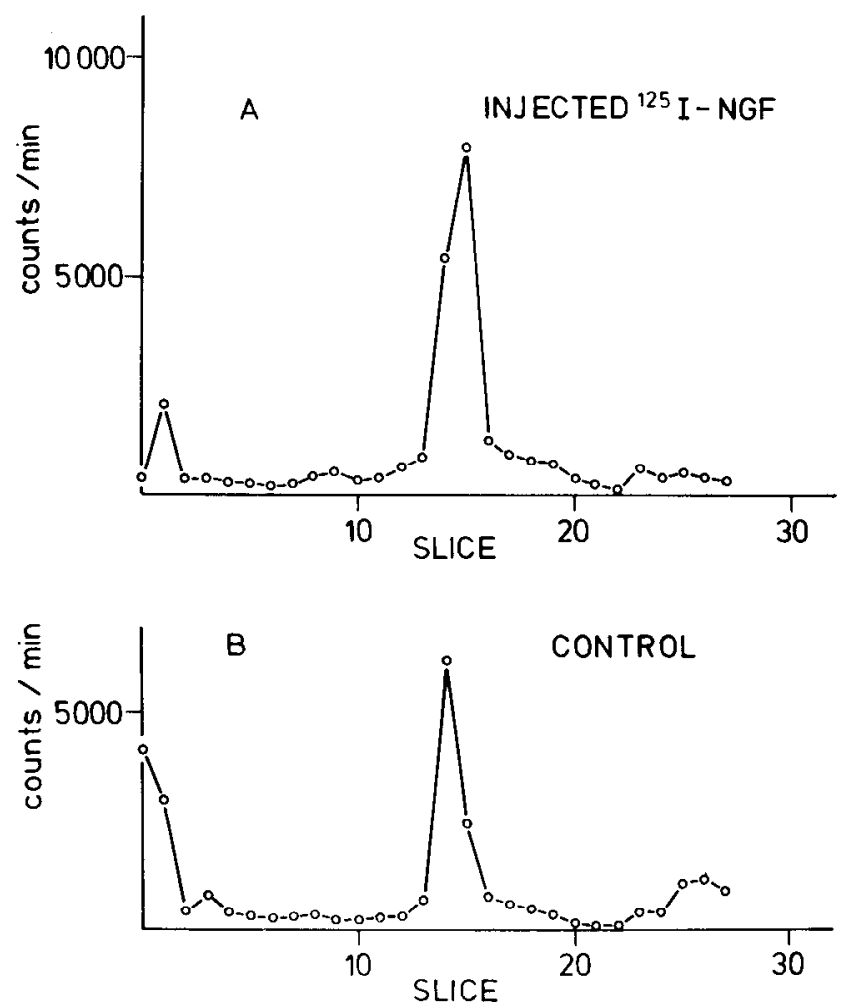

Figure 1. Electrophoretic mobilities of $\left[{ }^{125} \mathrm{I}\right]$ NGF before and after injection into PC12-FR cells. $A$, Three hours after fusion with FITCBSA and [ $\left.{ }^{125} \mathrm{I}\right] \mathrm{NGF}$ loaded ghosts $(0.39 \pm 0.01 \mathrm{cpm} / \mathrm{ghost})$, cells were detached, treated with trypsin, lysed, heat denatured, and subjected to SDS-PAGE in a $15 \%$ gel. $B,\left[{ }^{125} \mathrm{I}\right] \mathrm{NGF}$ was added to the pellet of nonfused cells and subjected to electrophoresis as in $A$ (for details see "Materials and Methods"). 

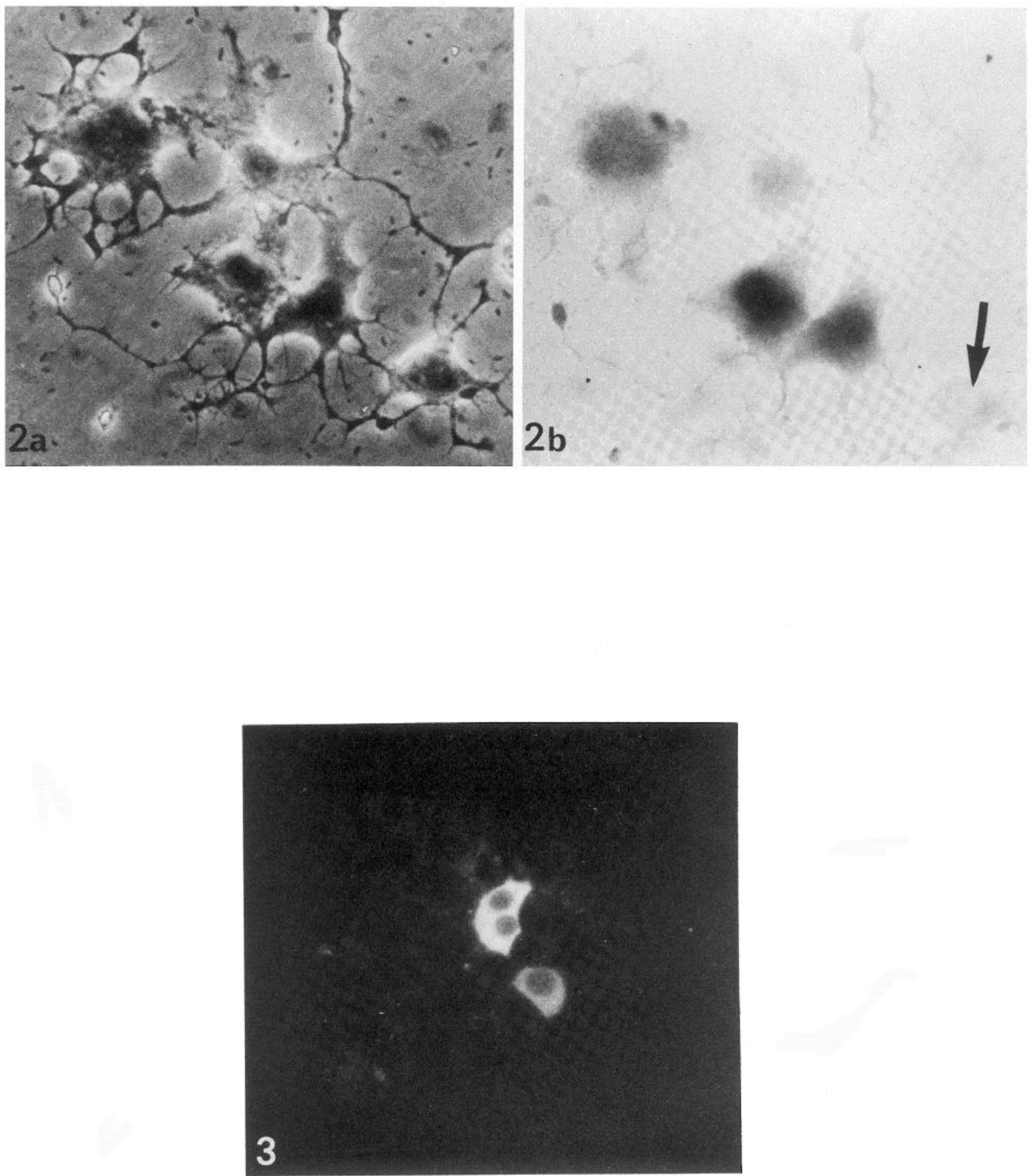

Figure 2. Light microscopic photographs of injected HRP-positive and noninjected cells (arrow). After fusion with ghosts containing FITCBSA, HRP and cytochrome $c$ cells were replated and incubated in the presence of $50 \mathrm{ng} / \mathrm{ml}$ of NGF for $48 \mathrm{hr}$. Glutaraldehyde-fixed cells were reacted for HRP visualization as described under "Materials and Methods." Phase contrast $(a)$ and brightfield $(b)$ pictures were taken from identical fields of the plate. Magnification $\times 220$.

Figure 3. Distribution of fluorescence of FITC-BSA $3 \mathrm{hr}$ after injection. Cells were detached and resuspended in PBS containing glucose (1 $\mathrm{gm} /$ liter) and sucrose (20 gm/liter), and photographic pictures were taken from the living cells under a Leitz fluorescence microscope.

density of 1 to $2 \times 10^{5}$ cells/3.5-cm dish on a polyornithine substrate to achieve a fast attachment after cell sorting. The cells were grown for $60 \mathrm{hr}$ in the absence or presence of $100 \mathrm{ng} / \mathrm{ml}$ of NGF in the culture medium and then assayed for ChAT activity.

\section{Determination of ChAT activity and immunotitration}

The harvested cells were disrupted by freezing and thawing and were taken up into $0.005 \mathrm{~m}$ Tris buffer containing $1 \%$ Triton X-100. ChAT activity was determined according to the method of Fonnum (1975) with a substrate concentration of $200 \mu \mathrm{M}\left[{ }^{14} \mathrm{C}\right]$ acetyl-CoA, (specific activity, $5.5 \mu \mathrm{Ci} / \mathrm{mmol}$; Amersham, Braunschweig, Federal Republic of Germany). In the immunotitration experiments, variable amounts of rabbit anti-ChAT antibodies raised against highly purified pig brain ChAT (Eckenstein and Thoenen, 1982) (cross-reacting with rat brain ChAT) in a volume of $10 \mu \mathrm{l}$ were added to $50 \mu \mathrm{l}$ of homogenate. The mixture was incubated for $30 \mathrm{~min}$ at room temperature and subsequently for $48 \mathrm{hr}$ at $4^{\circ} \mathrm{C}$. After centrifugation at $30,000 \mathrm{rpm}$ for $30 \mathrm{~min}$ 

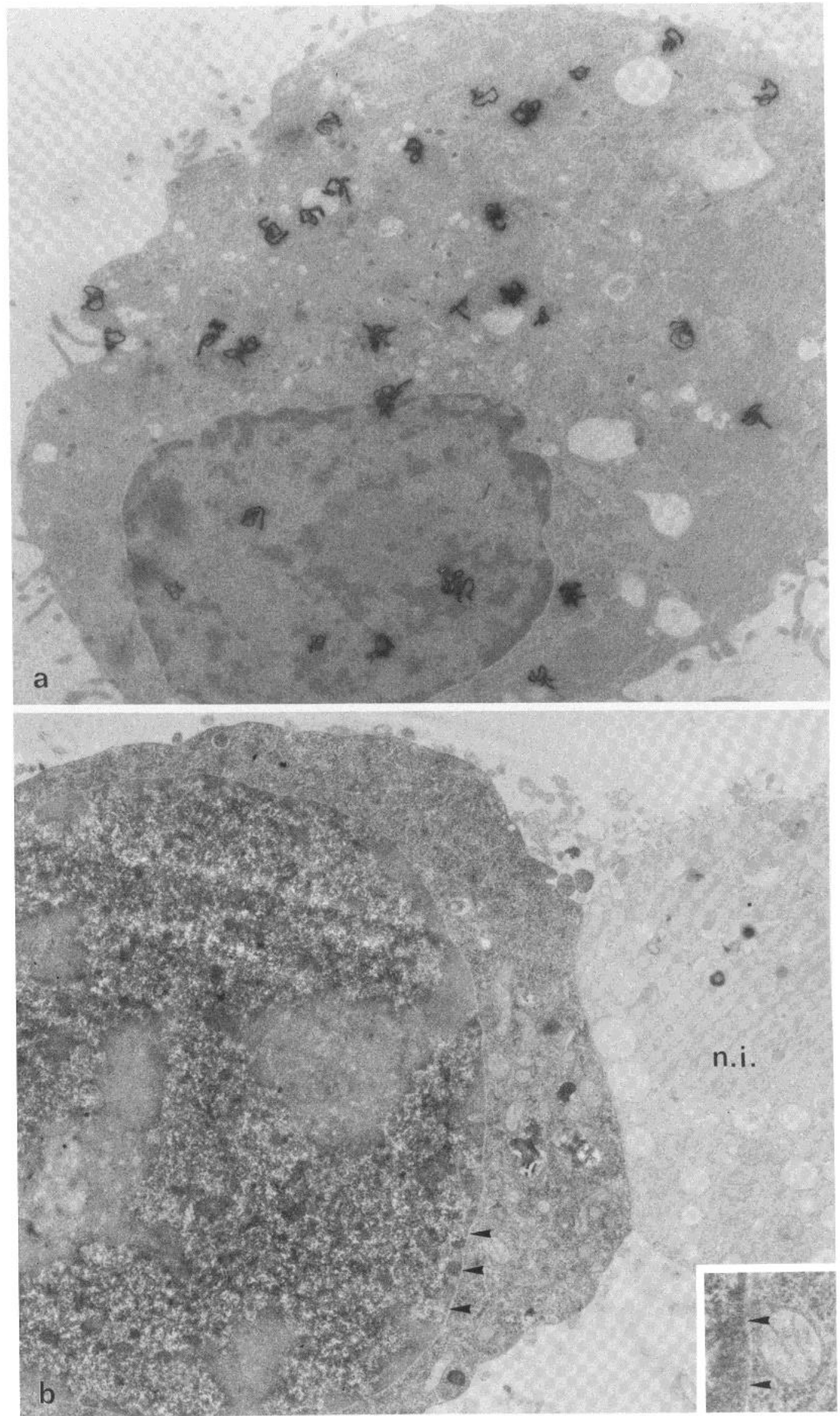

Figure 4. $a$, Electron microscopic autoradiogram of a PC12-FR cell $3 \mathrm{hr}$ after injection with $\left[{ }^{125} \mathrm{I}\right] \mathrm{NGF}$. NGF is distributed over the entire cell cytoplasm and the nucleus. Magnification $\times 10,800$. $b$, Histochemical localization of HRP co-injected with NGF. The Cytoplasm and nucleus contain HRP reaction product, but intracellular membrane compartments remain free of reaction product. The insert shows the nuclear cisterna contain HRP reaction product, but intracellular membrane compall. Magnification $\times 10,400$. Insert, magnification $\times 37,000$. $c$, High magnification of an HRP-injected cell with reaction product in the cytoplasm and nucleus $(N)$. Lumen of the endoplasmic reticulum, Golgi $(G)$ and perinuclear cisterna, and mitochondria contains no HRP. Magnification $\times 22,900$. 


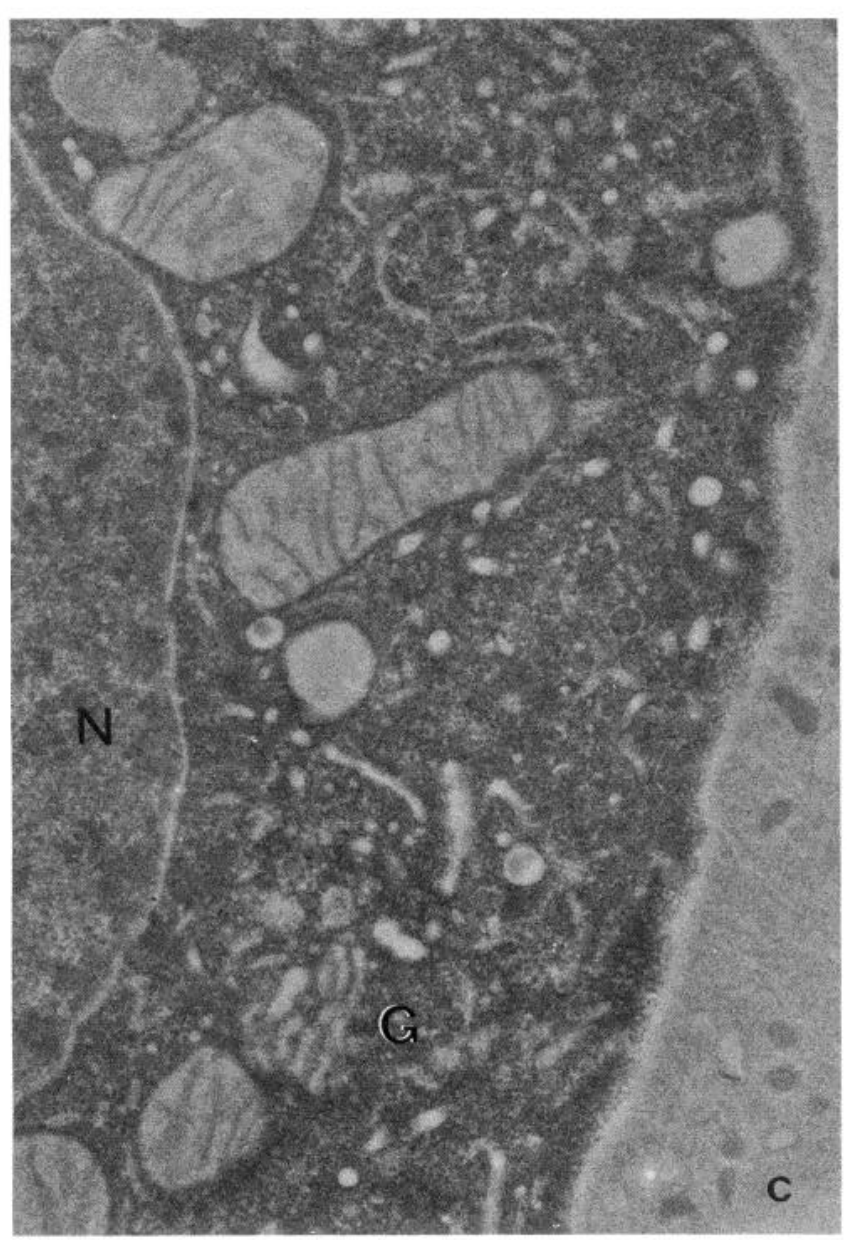

Figure $4 \mathrm{C}$

(rotor $60 \mathrm{Ti}$, Beckman, Munich, Federal Republic of Germany), ChAT activity was determined in the supernatant.

\section{Electron microscopy}

Two to $3 \mathrm{hr}$ after fusion with ghosts containing [ $\left.{ }^{125} \mathrm{I}\right] \mathrm{NGF}$, cells were treated with trypsin as described above, washed, centrifuged, and fixed for $1 \mathrm{hr}$ with $2.5 \%$ glutaraldehyde in $0.1 \mathrm{M}$ phosphate buffer $(\mathrm{pH} 7.4)$. Pellets were washed with phosphate buffer containing $5 \%$ sucrose, reacted for $\mathrm{HRP}$ visualization with $0.03 \%$ diaminobenzidine and $0.01 \%$ $\mathrm{H}_{2} \mathrm{O}_{2}$, washed, postfixed in $1 \% \mathrm{OsO}_{4}$ for $30 \mathrm{~min}$, dehydrated, and embedded in Epon 812. Sections ( $600 \AA)$ were coated with Kodak L4 emulsion and exposed for 3 months at $4^{\circ} \mathrm{C}$. Autoradiograms were developed with Microdol-X for 2 min and evaluated in a Zeiss EM 10 electron microscope.

Quantitative evaluation. In each section, all of the cells that were sectioned through the nucleus and contained more than 7 silver grains/ cell were photographed at a primary magnification of $\times 2160$. The area of cytoplasm and nucleus was measured on prints enlarged three times, and the total density of silver grains, as well as that over nucleus versus cytoplasm, was determined separately.

\section{Degradation studies}

\section{Determination of the nature of injected NGF $3 \mathrm{hr}$ after fusion}

PC12-FR cells injected with [ $\left.{ }^{125} \mathrm{I}\right] \mathrm{NGF}$ were washed seven times with CMF-PBS containing $0.1 \%$ BSA. Cells were then treated with $0.05 \%$ trypsin as described above, washed again, centrifuged, and lysed with sample buffer (Laemmli, 1970). After heat denaturation $\left(90^{\circ} \mathrm{C}\right.$ for 10 min), cellular proteins were subjected to SDS-PAGE in a $15 \%$ gel. As a control, noninjected cells were treated identically and [ $\left.{ }^{125} \mathrm{I}\right] \mathrm{NGF}$ was added to the cells just before lysis. The gels were sliced into $2-\mathrm{mm}$ pieces and counted in a gamma counter (Fig. 1). According to its electrophoretic mobility the injected $\left[{ }^{125} \mathrm{I}\right] \mathrm{NGF}$ was identical to native $\left[{ }^{125}\right.$ I]NGF.

\section{Time course of NGF degradation}

$N G F$ injected by ghost fusion. Four hours after injection with $\left[{ }^{125} \mathrm{I}\right]$ NGF, PC12-FR cells were washed six times with cold CMF-PBS containing $0.1 \%$ BSA and then treated with $0.05 \%$ trypsin for $10 \mathrm{~min}$ at $37^{\circ} \mathrm{C}$. (Note that incubation with trypsin was not performed at $0^{\circ} \mathrm{C}$ as described in the following section, since fused cells could not be detached from the polyornithine-coated dishes by trypsin at $0^{\circ} \mathrm{C}$.) The cells were then collected, washed two times with ice-cold serum-containing DMEM, and cultured in suspension in bacteriological dishes. In intervals of $8 \mathrm{hr}, 1-\mathrm{ml}$ aliquots of the cell suspension were removed. The cells were washed, collected by centrifugation through a BSAsucrose cushion $(0.1 \%$ BSA, $0.3 \%$ sucrose in $10 \mathrm{ml}$ of CMF-PBS; 800 $\times g$ for $5 \mathrm{~min}$ ), and the radioactivity present in the cells was determined. To evaluate the effect of leupeptin on the degradation of $\left.{ }^{125} \mathrm{I}\right] \mathrm{NGF}$ injected into the cytoplasm, the cells were pretreated with leupeptin $\left(10^{-4} \mathrm{M}\right)$ overnight before fusion and the same concentration of the protease inhibitor was present throughout the rest of the experiment.

Degradation of $\left[^{125}\right.$ IJ NGF taken up via cell surface receptors. Monolayer cultures of $\mathrm{PC} 12-\mathrm{FR}$ cells in $75-\mathrm{cm}^{2}$ tissue culture flasks (Falcon) were incubated with $\left[{ }^{125} \mathrm{I}\right] \mathrm{NGF}$ (300 ng/ml; specific activity, $27 \mu \mathrm{Ci} / \mu \mathrm{g}$ ) for $4.5 \mathrm{hr}$ at $37^{\circ} \mathrm{C}$. The cells were then washed seven times with cold CMF-PBS containing $0.1 \%$ BSA and treated with $0.05 \%$ trypsin for 20 min on ice. The cells were then collected, washed two times with icecold serum-containing DMEM, and cultured in suspension for various periods of time as described above. Aliquots of $100 \mu \mathrm{l}$ (corresponding to $50 \mu \mathrm{g}$ of cell protein) were removed and centrifuged $(800 \times g$ for 5 $\min )$ through a BSA-sucrose cushion $(1 \mathrm{ml})$, and the radioactivity present in the pellet then was determined. The treatment schedule and concentration of leupeptin were the same as in the injection experiment.

\section{Results}

Intracellular distribution of NGF, FITC-BSA, and HRP in PC12-FR cells after injection via fusion with erythrocyte ghosts

As rapid and independent indicators for the success of the injection, FITC-BSA and/or HRP were injected together with NGF. The intracellular distribution of these indicators was different. The entire cytoplasm (including neurites and growth cones when present) and the nuclear chromatin were penetrated by HRP $3 \mathrm{hr}$ after injection (Figs. 2 and 4), whereas FITC-BSA did not penetrate the nucleus within this time (Fig. $3)$. An unambiguous presence of FITC-BSA in the nucleus could not be detected before 24 to $48 \mathrm{hr}$ after injection. The electron microscopic localization of HRP confirmed the cytoplasmic and nuclear localization seen by light microscopy (Fig. $4 b$ ), i.e, the HRP reaction product was equally distributed throughout the cytoplasm and the nuclear chromatin, but the lumen of the intracellular membrane compartments (endoplasmic reticulum, Golgi apparatus, perinuclear space, and mitochondria) remained free of HRP (Fig. 4c). The only exception in this respect were the lysosomes, which occasionally contained some HRP probably as a consequence of autophagic activity. Typically, the rate of penetration of non-nuclear proteins from the cytoplasm into the nucleus seems to depend largely on their molecular weights (Paine et al., 1975). However, since HRP has a stronger tendency to accumulate in the nucleus, as is to be expected from its molecular weight (De Robertis, 1983), we studied the distribution of injected $\left[{ }^{125} \mathrm{I}\right]$ NGF by electron microscopic autoradiography. As shown in Figure $4 a$, silver grains were present both over the cytoplasm and the nucleus. The mean of the ratio between nuclear and cytoplasmic silver grain densities per square micrometer was $1.36 \pm 0.13$ (SEM; $n=27$ ), indicating a slight enrichment of $\left[{ }^{125} \mathrm{I}\right] \mathrm{NGF}$ in the cell nucleus. A histogram of the labeling densities for the whole cells showed that the analyzed population of cells was not labeled uniformly (Fig. 5). Comparing these results with those from the measurements of fluorescence 


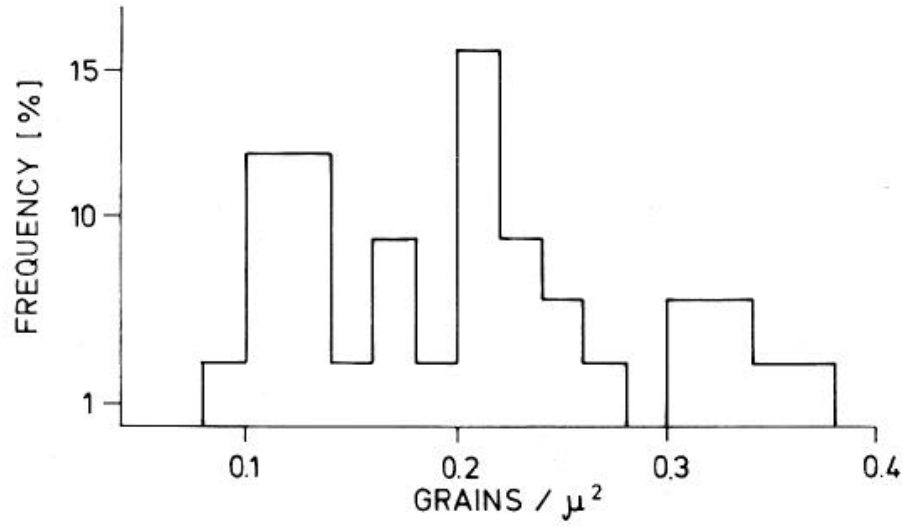

Figure 5. Labeling density histogram of $\left[{ }^{125} \mathrm{I}\right] \mathrm{NGF}$-injected cells ( $n$ $=32$ ). Three hours after fusion with ghosts loaded with $\left[{ }^{125} \mathrm{I}\right] \mathrm{NGF} /$ FITC-BSA ( $0.39 \pm 0.01 \mathrm{cpm} / \mathrm{ghost})$ cells were fixed and processed for electron microscopic autoradiography and the number of grains per cell was determined as described under "Materials and Methods."

intensity of single injected cells (see below), where a mean number of 2.6 fused erythrocytes/PC12-FR cell was obtained, the three peaks probably correspond to populations of $\mathrm{PC} 12$ cells fused with one, two, or three [ $\left.{ }^{125} \mathrm{I}\right]$ NGF loaded erythrocyte ghosts.

Comparison between the quantity of NGF injected by erythrocyte ghost fusion and receptor-mediated uptake. By including $\left[{ }^{125} \mathrm{I}\right] \mathrm{NGF}$ into the loading solution, we could determine the amount of NGF injected into the cells. In a typical experiment, one ghost contained $3.6 \mathrm{fg}$ or $8.3 \times 10^{4}$ molecules of NGF. The number of injected molecules depends on the number of ghosts that are fused to one cell. With the FACS the average fluorescence of the ghost population was compared with the average fluorescence of thousands of injected cells (Fig. 6). We found a ghost-to-cell ratio of $2.6 \pm 0.5$ in six independent experiments, representing an average number of $21.6 \times 10^{4}$ molecules of
$\mathrm{NGF}$ /injected cell. It should be noted that any changes in the fusion protocol, especially changes in the ratio between ghost and cell number (in this case $28 \pm 6, n=10$ ), would lead to different results. The number of injected molecules is expected to decay continuously by degradation. However, in the presence of leupeptin the $t_{1 / 2}$ of injected [ $\left.{ }^{125} \mathrm{I}\right] \mathrm{NGF}$ was prolonged to 24 hr (see Fig. 11), preserving more than $2.6 \times 10^{4}$ molecules of $\mathrm{NGF} /$ cell after $60 \mathrm{hr}$ of incubation (see below).

When PC12 cells were cultured in the continuous presence of $\left[{ }^{125} \mathrm{I}\right] \mathrm{NGF}(100 \mathrm{ng} / \mathrm{ml})$ for $24 \mathrm{hr}$, an average of $2.6 \times 10^{4}$ molecules of NGF were present per cell as a result of continuous uptake and degradation (Rohrer et al., 1982). Thus, at all time points of the injection experiments the number of injected NGF molecules exceeded the number of NGF molecules accumulated in PC12-RF cells by receptor-mediated uptake.

\section{NGF-mediated increase in ChAT activity}

$\mathrm{PC} 12-\mathrm{RF}$ cells respond to the addition of saturating concentrations of NGF (100 ng/ml) by an increase in ChAT activity which is linear between 12 and $60 \mathrm{hr}$ of NGF treatment (unpublished observation). To decide whether this effect resulted from activation of a given number of ChAT molecules or from an increase in their number, we performed immunotitration experiments. The slopes obtained from control and NGF treated cells clearly indicated that the increase in ChAT activity was correlated with a shift of the equivalence point and therefore resulted from an augmented number of enzyme molecules (Fig. 7).

\section{NGF-mediated ChAT induction: Site of action of NGF}

To establish the responsiveness of fusion-injected cells, cytochrome $c$-injected cells were enriched by sorting in a FACS on the basis of co-injected FITC-BSA. Both injected and noninjected cells responded to the addition of NGF $(100 \mathrm{ng} / \mathrm{ml})$ to the culture medium with an identical increase in ChAT activity (Fig. 8). This observation was the prerequisite for comparing $\mathrm{NGF}$ and cytochrome $c$-injected cells with respect to their

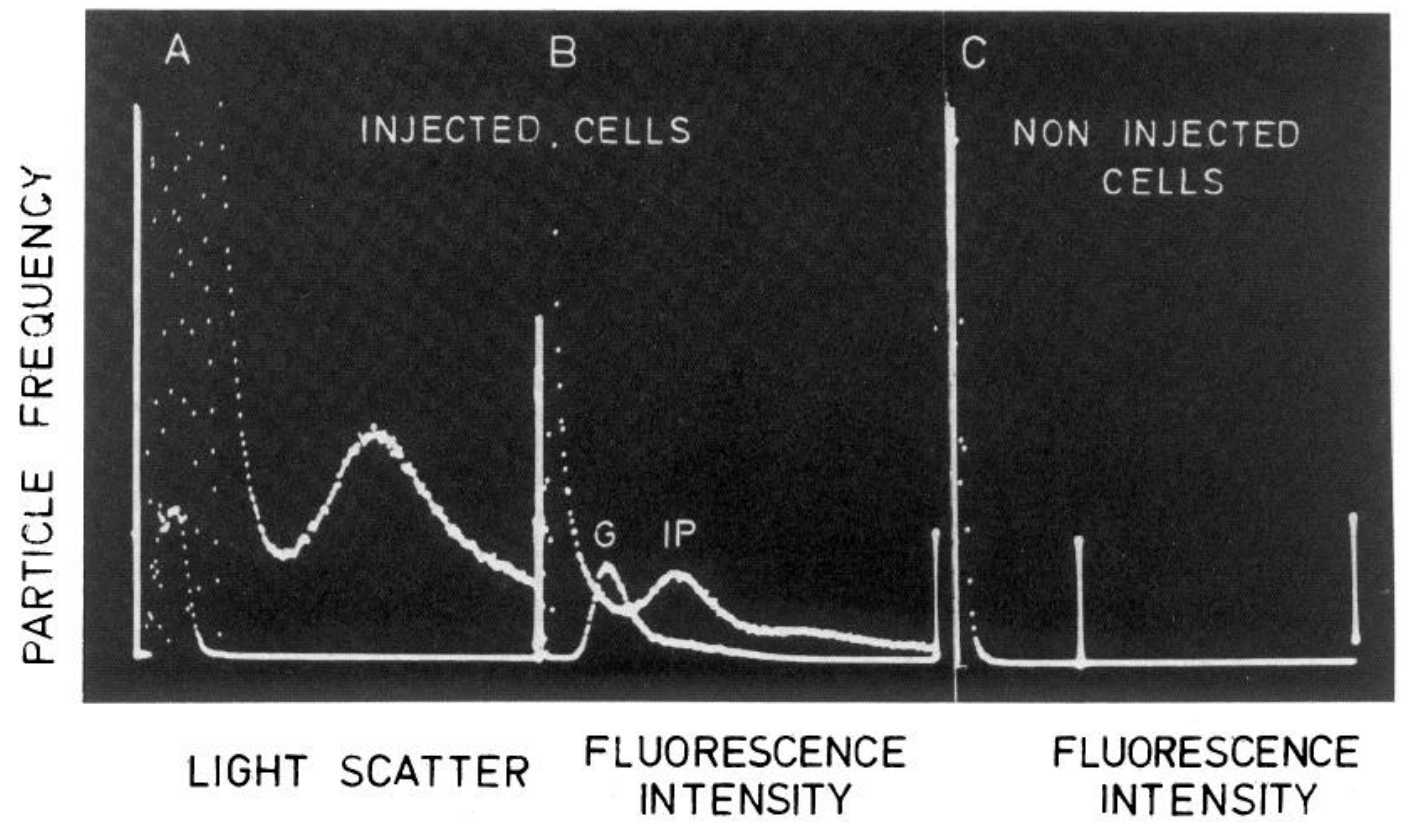

Figure 6. Histograms of the light scatter signals and of fluorescence intensities of injected cells (IP), ghosts $(G)$, and noninjected cells: $A$, Light scatter signals obtained from an injected cell population. $B$, Fluorescence intensities of injected cells $\left(n=1 \times 10^{5}\right)$ and of the ghosts used for fusion $3 \mathrm{hr}$ before. The expected decrease of fluorescence in the cells due to degradation of injected FITC-BSA during the 3-hr time period between fusion and fluorescence measurements was calculated to be less than $10 \%$ and could therefore be neglected (data not shown). The average number of ghosts that fused with one cell was determined by comparing the fluorescence intensity peaks obtained from ghosts and from injected cells (see the text for details). $C$, Fluorescence intensities of noninjected cells. 


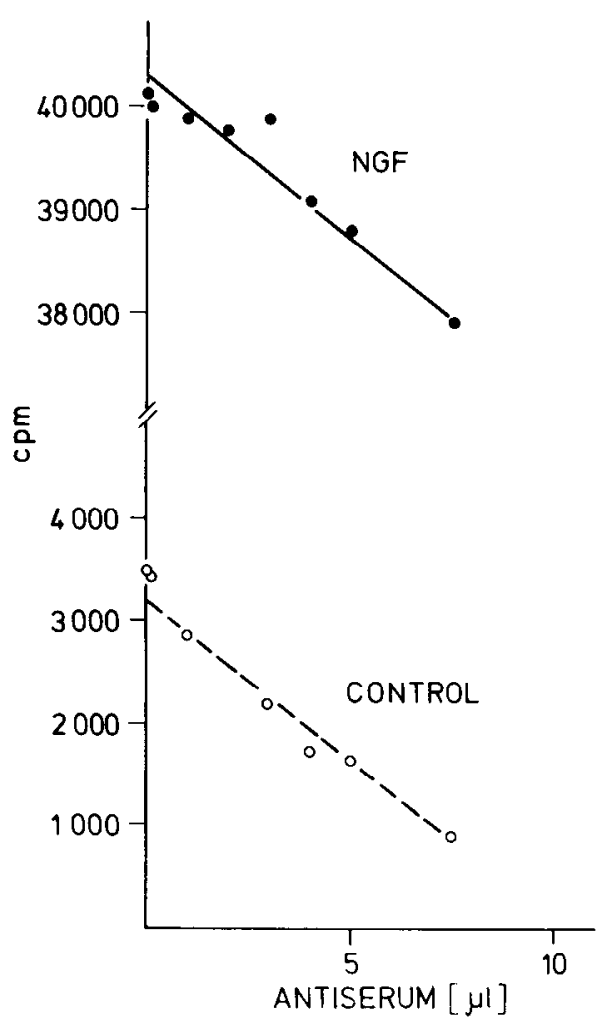

Figure 7. Immunotitration curves of ChAT activities in homogenates of cells grown in the absence (control) or presence of $100 \mathrm{ng} / \mathrm{ml}$ of NGF for 14 days. Specific activity of the homogenate was $188 \mathrm{pmol}$ of $\mathrm{AcCh} / \mathrm{min} / \mathrm{mg}$ of protein). The ChAT activities were determined in the supernatants after precipitation with ChAT-specific antibodies and after centrifugation as described under Materials and Methods."

ChAT content without prior enrichment by cell sorting. (It proved to be very difficult to obtain sufficiently large numbers of injected cells, necessary for reliable ChAT determination, by cell sorting since aggregation of cells could not be completely avoided.) When ChAT activities in cytochrome $c$ - and NGFinjected cells were compared after $60 \mathrm{hr}$ in culture in the absence or presence of $\mathrm{NGH}$ in the medium, the two populations were indistinguishable (Fig. 9). Thus, the direct introduction of NGF into the cell cytoplasm and its subsequent diffusion to the nucleus did not induce ChAT synthesis in contrast to NGF added to the culture medium and acting via membrane receptors. As in the case of fiber outgrowth, injection of NGF antibodies did not interfere with the ChAT induction produced by external NGF: an identical increase in ChAT activity was observed in antibody-injected and noninjected cells, and the NGF antibody injection also did not change the base line level of ChAT (Fig. 10).

\section{Rates of degradation of intracellular NGF}

The half-lives of [ $\left.{ }^{125} \mathrm{I}\right] \mathrm{NGF}$ injected into PC12-FR cells by erythrocyte ghost fusion or taken up by receptor-mediated internalization from the culture medium were compared in the absence and presence of the protease inhibitor leupeptin (Tanaka, 1983). $\left[{ }^{125} I\right] N G F$ taken up by endocytosis from the culture medium via specific NGF receptors was very rapidly degraded, with a $t_{1 / 2}$ of $40 \mathrm{~min}$ (Fig. 11A). This rapid degradation corresponds to the rapid transfer of internalized NGF to lysosomal structures described previously (Rohrer et al., 1982; Layer and Shooter, 1983) (Fig. 12). Leupeptin strongly inhibited the NGF degradation, increasing the $t_{1 / 2}$ to $24 \mathrm{hr}$ (Fig. 11A). In contrast to the internalized NGF, the $t_{1 / 2}$ of [ $\left.{ }^{125} \mathrm{I}\right] \mathrm{NGF}$ injected by erythrocyte fusion into the cytoplasm was much longer; i.e., the $t_{1 / 2}$ was $10 \mathrm{hr}$ and leupeptin increased it to $24 \mathrm{hr}$ (Fig. 11B). In addition to the ability of leupeptin to strongly impair NGF degradation (especially that of internalized NGF), these results also demonstrate that injected NGF is present in the cytoplasm and nucleus for a sufficiently long time in a sufficiently high concentration.

\section{Effect of leupeptin on NGF-mediated ChAT induction}

To test the possibility that a breakdown product of NGF which is not recognized by NGF antibodies would act as a second messenger, the lysosomal degradation of NGF was blocked by leupeptin, and the effect on NGF-mediated ChAT induction was examined. As shown in Figure 13, leupeptin did not have any effect on the NGF-mediated ChAT induction under experimental conditions under which the half-life of NGF taken up by endocytosis was prolonged from $40 \mathrm{~min}$ to $24 \mathrm{hr}$ (see above). Since the dose-response curve of ChAT to NGF is very steep (Heumann et al., 1983), an alteration in the effect of NGF should become more readily apparent at subsaturating concentrations of NGF. However, leupeptin did not influence the response of ChAT at either subsaturating or saturating concentrations of NGF (Fig. 13). These data indicate that a lysosomal breakdown product of NGF is not mediating ChAT induction, nor does the accumulation of intact NGF in lysosomal compartments enhance the effect of a given concentration of NGF in the culture medium.

\section{Discussion}

Although the interaction of NGF with its plasma membrane receptors has been characterized very extensively (Costrini and Bradshaw, 1979; Sutter et al., 1979; Naujoks et al., 1982; Hosang and Shooter, 1983; Puma et al., 1983), the events following this ligand-receptor interaction remain to be elucidated. At least three alternative possibilities exist: $(i)$ the formation of a second messenger(s) could be initiated by the interaction of NGF with its receptors, either immediately after NGF binding at the cell membrane or following internalization and (in neurons) retrograde axonal transport; (ii) NGF itself reaches the free cell cytoplasm and the nucleus where it interacts directly with cytoskeletal elements (fiber outgrowth) (Calissano and Cozzari, 1974; Nasi et al., 1982) or with nuclear binding sites (Andres et al., 1977; Bradshaw, 1983) involved in the regulation of the expression of specific genetic information such as transmittersynthesizing enzymes; or (iii) NGF could be broken down in the lysosomal compartment, and small peptides resulting from NGF breakdown could be released into the cytoplasm to act directly on target elements.

The localization of NGF by electron microscopic autoradiography in PC12 cells (Hogue-Angeletti et al., 1982; Rohrer et al., 1982; Bernd and Greene, 1983), in sympathetic neurons following retrograde transport in vivo (Schwab and Thoenen, 1977), and in sympathetic neurons in vitro (Claude et al., 1982) along with the electron microscopic localization of an NGFHRP coupling product during and after retrograde axonal transport (Schwab, 1977) all indicates that NGF is rapidly internalized subsequent to its binding to the membrane receptors and reaches the cell body in tubular or vesicular membrane compartments, which finally fuse with lysosomes. However, the limits of the sensitivity and spatial resolution of these methods do not exclude that a very small amount (below 3 to $5 \%$ ) of internalized NGF escapes into the free cytoplasm and also reaches the nucleus. Indeed, such "escape mechanisms" exist for a few specific molecules. The toxic subunits of diphtheria toxin and ricin penetrate through the membrane (Donovan et al., 1982) of lysosomes or the cell membrane under appropriate conditions (low pH) (Draper and Simon, 1980) and interact with cytoplasmic constituents (Olsnes et al., 1975; Pappenheimer, 1977). Entry into the cytoplasm by plain rupture of 


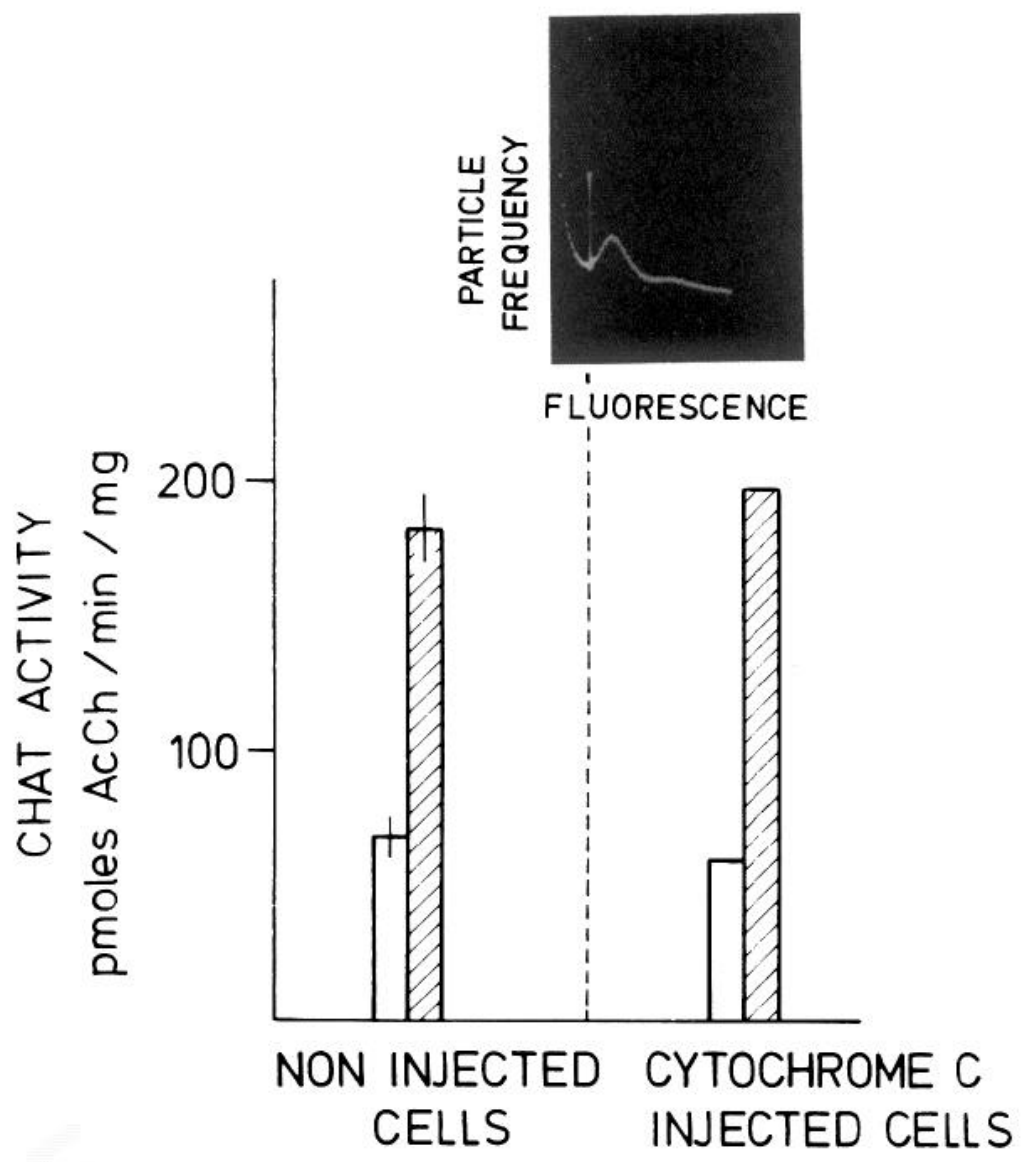

Figure 8. Induction of ChAT by NGF in PC12-FR cells after injection of cytochrome $c$ /FITC-BSA and subsequent cell sorting. Insert, Histogram of the fluorescence signals excited from injected cells. The vertical bar indicates the position of the sorting signal. Cells with lower fluorescence intensity than indicated by the sorting signal (noninjected cells, left panel) were separated from those of fluorescence intensity exceeding that of the sorting signal (cytochrome $c$ injected cells, right panel). After cell sorting, the frequency of injected cells $(I F)$ was determined from aliquots of the cell suspensions (noninjected, $I F=1 \%$; cytochrome $c, I F=55 \pm$ $6 \%$ ), and the replated cells were incubated for $60 \mathrm{hr}$ in the absence (open bars) or presence (hatched bars) of $100 \mathrm{ng} / \mathrm{ml}$ of NGF. Fusion, cell culture, and determination of ChAT specific activity were performed as detailed under "Materials and Methods."

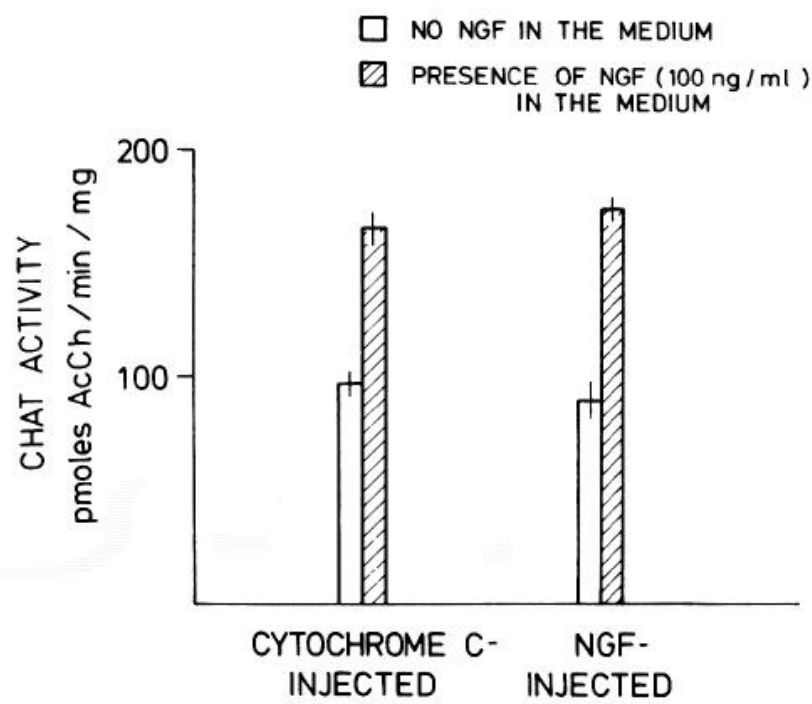

Figure 9. Induction of ChAT by NGF after injection of cells with cytochrome $C$ /FITC-BSA or NGF/FITC-BSA. Three hours after fusion the frequency of injected cells $(I F)$ was determined under the fluorescence microscope (cytochrome $c, \mathrm{IF}=28 \pm 5 \%$; NGF: IF $=34$ $\pm 6 \%$ ). Cells were replated and incubated for $60 \mathrm{hr}$ in the absence (open bars) or presence (hatched bars) of $100 \mathrm{ng} / \mathrm{ml}$ of NGF in the medium as described in the legend to Figure 8 . Error bars indicate SEM $(n=4)$ in all figures. Leupeptin $\left(10^{-4} \mathrm{M}\right)$ was also added to the incubation medium in order to decrease the rate of degradation of injected NGF (see also Figs. 11 and 13). intracellular membrane compartments (formed by endocytosis) has recently been shown for nonenveloped adenoviruses (Fitzgerald et al., 1983). By this mechanism the adenovirus can also mediate the transfer of epidermal growth factor (EGF) into the free cytoplasm, whereas EGF interacting alone with its target cells is internalized into membrane-confined compartments (Cuatrecasas, 1982; Willingham, 1983). Experimentally, the release of HRP into the cytoplasm can also be produced by osmotic rupture of endocytic vesicles which were previously loaded with HRP by fluid phase endocytosis (Okada and Rechsteiner, 1982). Such mechanisms had to be invoked in order to transfer a macromolecule like NGF into the free cytoplasm of target cells. Therefore, the crucial experiment to decide between a second-messenger mechanism or a direct action of NGF in the free cytoplasm was to introduce NGF into the cytoplasm and the nucleus of NGF-responsive cells, and to evaluate the effect of similarly injected anti-NGF antibodies on the response to NGF interacting with plasma membrane receptors.

Since enzyme measurements generally require relatively large numbers of injected cells, needle injections (Seeley et al., 1983) would not be efficient enough; thus, a fusion method had to be used for these experiments. So far, this approach has been used in only a few cases for the biochemical evaluation of the biological action of macromolecules. For instance, the action of diphtheria toxin was completely abolished by cytoplasmic injection (using Sendai virus as a fusogen) of antibodies against the toxic subunit (Yamaizumi et al., 1979), and fibroblasts injected with antibodies directed against SV40 large tumor (T) and small tumor $(\mathrm{t})$ antigens were protected from transformation by SV40 (Antman and Livingston, 1980).

In the present study we used the fusion approach to delineate the site of action of NGF in PC12-FR cells with respect to 


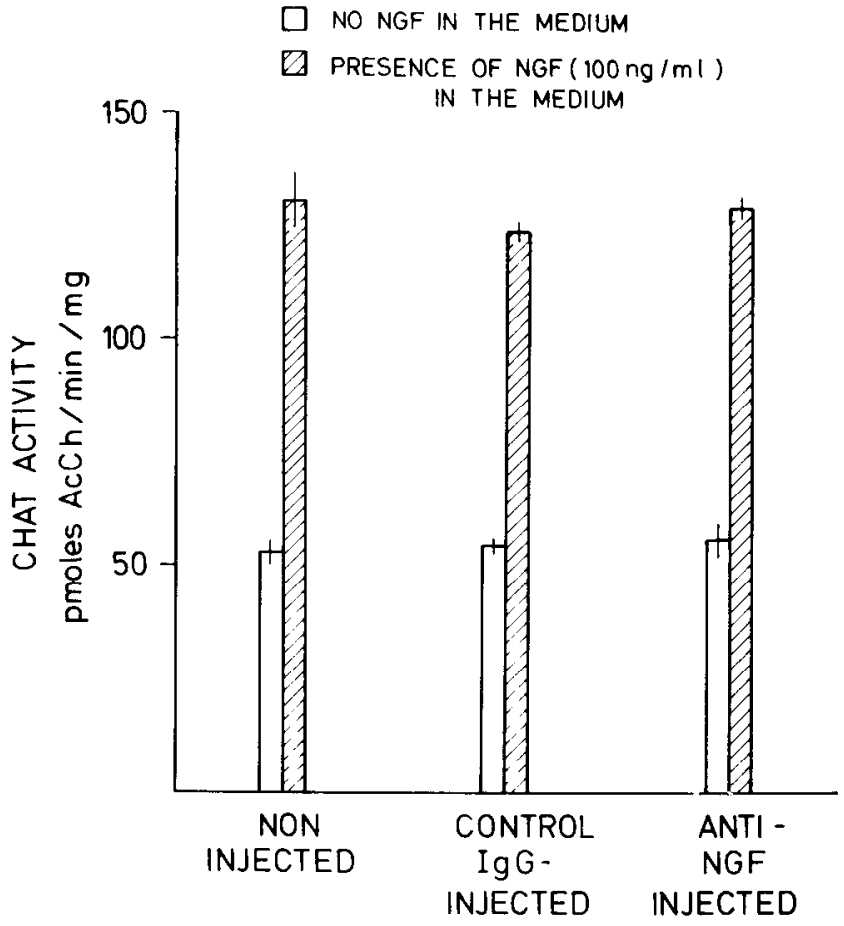

Figure 10. Induction of ChAT by NGF after injection of cells with control IgG/FITC-BSA or affinity-purified NGF antibodies/FITCBSA. Noninjected cells, treated by exactly the same fusion protocol as the injected cells but omitting the ghosts, were also tested for their response to NGF (control cells). Fusion, incubation of cells in the absence (open bars) or presence of $100 \mathrm{ng} / \mathrm{ml}$ of NGF (hatched bars), and determination of ChAT specific activity were as described in the legend to Figure 9. The average amount of injected NGF antibodies was equivalent to that needed to neutralize $21 \times 10^{4} \mathrm{NGF}$ molecules. Frequencies of IgG-injected and of anti-NGF-injected cells were $23 \pm$ $6 \%$ and $28 \pm 2.5 \%$, respectively.

ChAT induction. Cytochrome $c$-injected and noninjected cells reacted to NGF added to the culture medium in an identical way, indicating that the viability and the responsiveness of PC12-FR cells to NGF was not changed by the injection procedure. Furthermore, intracellularly there was no inhibitory effect produced from the relatively high initial concentrations of NGF (Fig. 9). In the absence of exogenous NGF, NGFinjected cells did not show any change in ChAT activity and, also, in confirmation of earlier experiments, no fiber outgrowth (Heumann et al., 1981). The number of NGF molecules present in PC12-FR cells after ghost injection was, on the average, slightly higher during the whole duration of the experiment of 60 hr than was the steady-state concentration of NGF molecules present in PC12 cells after uptake from the culture medium (100 ng/ml of NGF) representing the result of continuous endocytosis and lysosomal degradation. Since the half-life of injected NGF was relatively long $(10 \mathrm{hr})$, the concentrations of NGF after injection would have been sufficient to elicit ChAT induction. Electron microscopic autoradiography of $\left[{ }^{125} \mathrm{I}\right]$ NGF-injected cells confirmed the distribution of the injected NGF throughout the cytoplasm and the nucleus. Also, in confirmation of earlier studies on NGF-mediated fiber outgrowth (Heumann et al., 1981; Scclcy ct al., 1983), injection of affinitypurified NGF antibodies did not inhibit the increase in ChAT activity by NGF added to the culture medium. These results thus rule out conclusively that NGF itself, a modified NGF molecule, or NGF fragments which still are recognized by NGF polyclonal antibodies act as intracellular cytoplasmic or nuclear messengers.

The theoretical possibility exists that NGF might be subjected to a nonproteolytic modification so that it is not recognized by NGF antibodies. However, the following experimental observations argue against such a possibility. (i) Even a modified NGF, after its hypothetical passage through membranes, should have the same intracellular distribution as injected $\mathrm{NGF}$, in particular, the equal distribution between cytoplasm and nucleus. This distribution, however, has never been observed (Schwab, 1977; Schwab and Thoenen, 1977; Rohrer et al., 1982). (ii) The hypothetical modification would have to be very subtle since it was not detectable by SDS-PAGE when internalized and native NGF were compared (Dumas et al., 1979). (iii) More than 95\% of labeled NGF recovered in the low speed supernatant of rat dorsal root ganglia after retrograde axonal transport was still recognized by polyclonal anti-NGF antibodies (Stoeckel et al., 1975).

Our degradation studies using pulse experiments showed that exogenous NGF, taken up via cell surface receptors, is degraded very rapidly at a $t_{3 / 2}$ of $40 \mathrm{~min}$. This is in agreement with previous electron microscopic autoradiographic studies showing early lysosomal labeling (Rohrer et al., 1982). If degradation
A

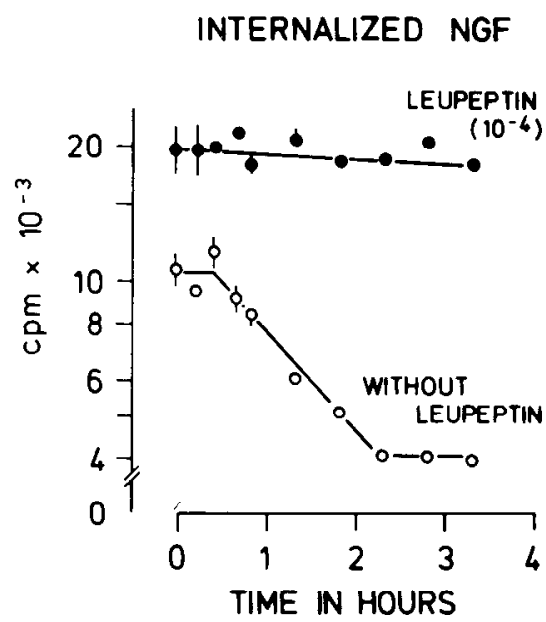

INJECTED NGF

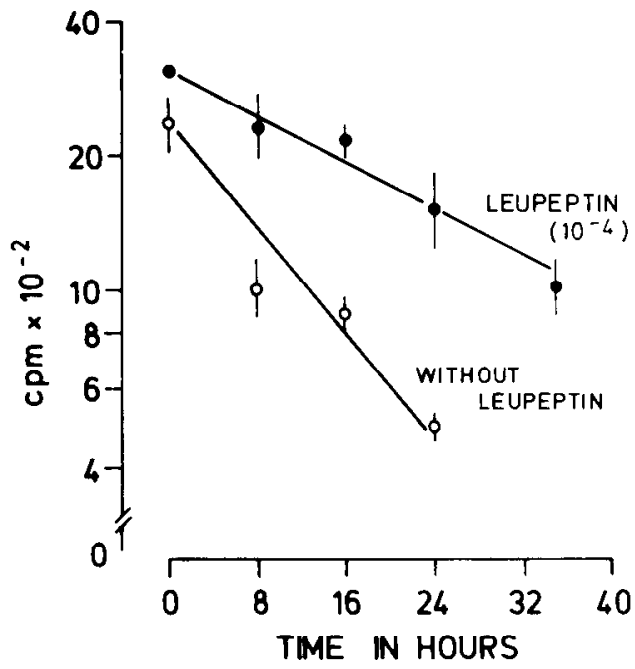

Figure 11. Effect of leupeptin $\left(10^{4} \mathrm{M}\right)$ in the medium upon the rates of degradation of internalized $\left[{ }^{125} \mathrm{I}\right] \mathrm{NGF}(A)$ and of injected $\left[{ }^{125} \mathrm{I}\right]$ NGF $(B) . A$, The rate of degradation of internalized NGF was derived from the regression line drawn through the logarithmic decay phase of the curve. The radioactivity associated with the cells at any time point was by $80 \%$ intact $\mathrm{NGF}$ as judged from the mobility of the radioactive material in a $15 \%$ SDSPAGE. $B$, Fusion of cells with [ $\left.{ }^{125} I\right] N G F /$ FITC-BSA $(0.12 \pm 0.006 \mathrm{cpm} /$ ghost $)$ and determination of cell-associated radioactivity as described under "Materials and Methods." 


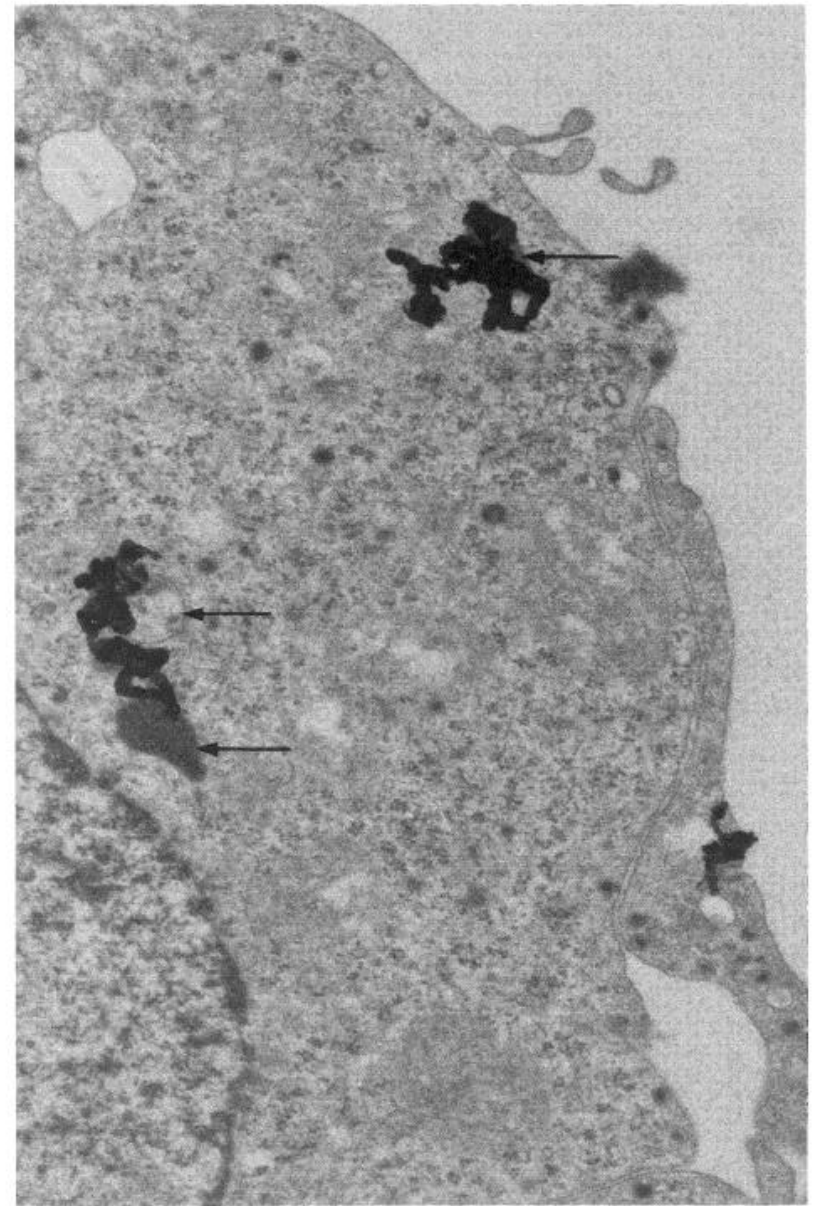

Figure 12. Electron microscopic localization of internalized $\left[{ }^{125} \mathrm{I}\right]$ NGF in secondary lysosomes of PC12 cells $1 \mathrm{hr}$ after addition of $\left.{ }^{[125} \mathrm{I}\right]$ NGF $(100 \mathrm{ng} / \mathrm{ml})$ to the culture medium as described by Rohrer et al. (1982). Arrows point to labeled dense bodies and multivesicular bodies. Magnification $\times 20,700$.

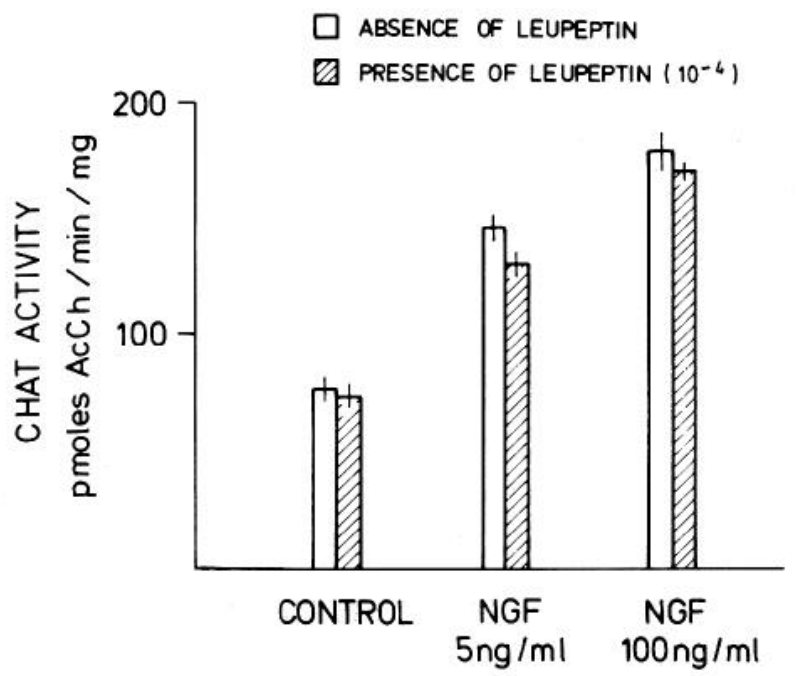

Figure 13. Effect of leupeptin on the induction of ChAT after incubation of cells for $60 \mathrm{hr}$ at saturating $(100 \mathrm{ng} / \mathrm{ml})$ or subsaturating concentrations ( $5 \mathrm{ng} / \mathrm{ml}$ ) of NGF or without NGF in the medium. Open bars, without leupeptin; hatched bars, with leupeptin $\left(10^{-4} \mathrm{M}\right)$. products released from the lysosomes (Layer and Shooter, 1983) act as second messengers, the blockade of lysosomal enzymes should greatly depress the NGF effects. However, whereas the $t_{1 / 2}$ of internalized [ $\left.{ }^{125} I\right] N G F$ was prolonged by leupeptin from $40 \mathrm{~min}$ to $24 \mathrm{hr}$, the increase in ChAT activity was indistinguishable from controls. Since much more NGF was present in the cells in the presence of leupeptin, the unchanged ChAT response in this experiment also indicates that the total amount of NGF accumulating in the lysosomes has no significance for ChAT induction. These observations agree with those made with EGF in which leupeptin did not influence the mitogenic response to EGF (Savion et al., 1980; Greenberg and Rozengurt, 1982).

It remains an open question whether the second messenger which now has to be postulated is one and the same for all of the biological actions of NGF; i.e., effects occurring within minutes, such as chemotactic effects on growth cones (Gunderson and Barrett, 1980; Seeley and Greene, 1983), and slow effects involving the regulation of the synthesis of specific proteins in the cell body at the transcriptional or post-transcriptional level (Rohrer et al., 1978; Hefti et al., 1982). From in vivo studies it is known that NGF administered to peripheral sympathetic nerve terminals leads to a specific increase in the synthesis of tyrosine hydroxylase in the cell body (Paravicini et al., 1975) and, later, to an increase in neuronal cell volume (Hendry, 1977). Therefore, either the second messenger has to be able to undergo (rapid) retrograde axonal transport as does NGF, or the NGF receptor complex is able to induce second messengers not only immediately after NGF binding in the cell surface membrane but also hours later, subsequent to its arrival in the cell body by retrograde transport. For EGF and also for insulin it has been shown that clustering of the receptor in the cell membrane is crucial for triggering subsequent intracellular events such as initiations of glucose oxidation or of mitosis (Schechter et al., 1979a, b). In fact, these responses can be produced by antibodies directed against the receptors (Kahn et al., 1978; Schreiber et al., 1983), suggesting that the ligands themselves are important only in their action on the receptor but do not serve any intracellular function. Proteolytic modification of the receptor or of an as yet unknown protein in response to ligand binding has been suggested for insulin as well as EGF (Cuatrecasas, 1982; Jarett et al., 1982; Larner et al., 1982; Seals and Czech, 1982; Gates and King, 1983). In the light of the present results showing that the full response to NGF can be triggered in the presence of the protease inhibitor leupeptin, it is interesting that EGF-induced proteolytic fragmentation of the EGF receptor is resistant to leupeptin (Cassel and Glasen, 1982). Thus, the present experiments eliminate the possibility that a lysosomal degradation product of NGF itself acts as a second messenger, but they do not allow the exclusion of other receptor-mediated proteolytic events.

In conclusion, the regulation of the synthesis of ChAT cannot be effected through cytoplasmic or nuclear NGF binding sites. This is corroborated by the finding that NGF antibodies present in the cell cytoplasm do not antagonize effects triggered by NGF receptor interactions, indicating that the penetration of small amounts of NGF into the cytoplasm or the nucleus, if occurring at all, is of no physiological relevance. Strong inhibition of the rapid degradation of NGF by leupeptin after the receptor-mediated internalization did not alter the concentration-dependent induction of ChAT, suggesting that a lysosomal proteolytic cleavage product of NGF is also not acting as an intracellular second messenger.

\section{References}

Andres, R. Y., I. Jeng, and R. Bradshaw (1977) Nerve growth factor receptors: Identification of distinct classes in plasma membranes and 
nuclei of embryonic dorsal root neurons. Proc. Natl. Acad. Sci. U. S. A. $74: 2785-2789$.

Antman, K. H., and D. M. Livingston (1980) Intracellular neutralization of SV40 tumor antigens following microinjection of specific antibody. Cell 19: 627-635.

Banerjee, S. P., S. H. Snyder, P. Cuatrecasas, and L. A. Greene (1973) Binding of nerve growth factor receptor in sympathetic ganglia. Proc. Natl. Acad. Sci. U. S. A. 70: 2519-2523.

Bernd, P., and L. A. Greene (1983) Electron microscopic radioautographic localization of iodinated nerve growth factor bound to and internalized by PC12 cells. J. Neurosci. 3: 631-643.

Bocchini, V., and P. U. Angeletti (1969) The nerve growth factor: Purification as a 30,000-molecular weight protein. Proc. Natl. Acad. Sci. U. S. A. 64 : $787-794$.

Bradshaw, R. A. (1983) Nerve growth factor and related hormones. In Biochemical Actions of Hormones, G. Litwack, ed., pp. 91-114, Academic Press, Inc., New York.

Calissano, P., and C. Cozzari (1974) Interaction of nerve growth factor with the mouse-brain neurotubule protein(s). Proc. Natl. Acad. Sci. U. S. A. 71: 2131-2135.

Cassel, D., and L. Glasen (1982) Proteolytic cleavage of epidermal growth factor receptor. J. Biol. Chem. 257: 9845-9848.

Claude, Ph., E. Hawrot, and I. Parada (1982) Ultrastructural studies of the intracellular faie of ${ }^{19 s}$ I-nerve growth factor in cultured rat sympathetic neurons. J. Cell Biochem. 20: 1-13.

Costrini, N. V., and R. A. Bradshaw (1979) Binding characteristics and apparent molecular size of detergent solubilized nerve growth factor receptor of sympathetic ganglia. Proc. Natl. Acad. Sci. U. S. A. 76: $3242-3245$.

Cuatrecasas, P. (1982) Epidermal growth factor: Uptake and fate. Ciba Found. Symp. 92: 96-108.

DeRobertis, E. M. (1983) Nucleocytoplasmic segration of proteins and RNAs. Cell 32: 1021-1025.

Donovan, J. J., M. I. Simon, and M. Montal (1982) Insertion of diptheria toxin into and across membranes: Role of phosphoinositide asymmetry. Nature 298: 669-672.

Draper, R. K., and M. I. Simon (1980) The entry of diphtheria toxin into the mammalian cell cytoplasm: Evidence for lysosomal involvement. J. Cell Biol. 87: 849-854.

Dumas, M., M. Schwab, and H. Thoenen (1979) Retrograde axonal transport of specific macromolecules as a tool for characterizing nerve terminal membranes. J. Neurobiol. 10: 179-197.

Eckenstein, F., and H. Thoenen (1982) Production of specific antisera and monoclonal antibodies to choline acetyltransferase: Characterization and use for identification of cholinergic neurons. EMBO J. 1: 363-368.

Edgar, D., and H. Thoenen (1978) Selective enzyme induction in a nerve growth factor-responsive pheochromocytoma cell line (PC12). Brain Res. 154: 186-190.

Fitzgerald, D. J. P., R. Padmanabhan, I. Pastan, and M. C. Willingham (1983) Adenovirus-induced release of epidermal growth factor and pseudomonas toxin into the cytosol of $\mathrm{KB}$ cells during receptormediated endocytosis. Cell 32: 607-617.

Fonnum, F. (1975) A rapid radiochemical method for the determination of choline acetyltransferase. J. Neurochem. 24: 407-409.

Gates, R. E., and L. E. King (1983) Proteolysis of the epidermal growthfactor receptor by endogenous calcium-activated neutral protease from rat liver. Biochem. Biophys. Res. Commun. 113: 255-262.

Greenberg, P. L., and E. Rozengurt (1982) Role of intracellular degradation of epidermal growth factor in mitogenesis. Exp. Cell Res. 142: 111-117.

Greene, L. A., and J. C. McGuire (1978) Induction of ornithine decarboxylase by nerve growth factor dissociated from effects of survival and neurite outgrowth. Nature 276: 191-194.

Greene, L. A., and A. Rukenstein (1981) Regulation of acetylcholinesterase activity by nerve growth factor. J. Biol. Chem. 256: 6363-6367.

Greene, L. A., and A. Tischler (1976) Establishment of a noradrenergic clonal line of rat adrenal pheochromocytoma cells which respond to nerve growth factor. Proc. Natl. Acad. Sci. U. S. A. 73: 2424-2428.

Gunderson, R. W., and J. N. Barrett (1980) Characterization of the turning response of dorsal root neurites towards nerve growth factor. J. Cell Biol. 87: 546-554.

Hatanaka, H., U. Otten, and H. Thoenen (1978) Nerve growth factormediated selective induction of ornithine decarboxylase in rat phe- ochromocytoma: A cyclic AMP-independent process. FEBS Lett. 92: 313-316.

Hefti, F., H. Gnahn, M. E. Schwab, and H. Thoenen (1982) Induction of tyrosine hydroxylase by nerve growth factor and by elevated $\mathrm{K}^{+}$ concentrations in cultures of dissociated sympathetic neurons. J. Neurosci. 2: 1554-1566.

Hendry, I. A. (1977) The effect of retrograde axonal transport of nerve growth factor on the morphology of adrenergic neurons. Brain Res. 134: 213-223.

Heumann, R., M. E. Schwab, and H. Thoenen (1981) A second messenger required for nerve growth factor biological activity? Nature 292: 838-840.

Ileumann, R., V. Kachel, and H. Thoenen (1983) Relationship between NGF-mediated volume increase and "priming effect" in fast and slow reacting clones of PC12 pheochromocytoma cells. Exp. Cell Res. 145: $179-190$.

Hogue-Angeletti, R., A. Stieber, and N. K. Gonatas (1982) Endocytosis of nerve growth factor by PC12 cells studied by quantitative ultrastructural autoradiography. Brain Res. 241: 145-156.

Hosang, M., and E. M. Shooter (1983) Detection of two types of nerve growth factor receptor by affinity labeling. Trans. Am. Soc. Neurochem. 14: 223.

Jarett, L., F. Kiechle, and J. C. Parker (1982) Chemical mediator or mediators of insulin action: Response to insulin and mode of action. Fed. Proc. 41: 2736-2741.

Kahn, C. R., K. L. Baird, D. B. Jarrett, and J. S. Flair (1978) Direct demonstration that receptor crosslinking or aggregation is important in insulin action. Proc. Natl. Acad. Sci. U. S. A. 75: 4109-4213.

Laemmli, U. K. (1970) Cleavage of structural proteins during assembly of the head of bacteriophage T4. Nature 227: 680-682.

Larner, J., K. Cheng, C. Schwartz, K. Kikuchi, S. Tamura, S. Creacy, R. Dubler, G. Galaskn, C. Pullin, and M. Katz (1982) A proteolytic mechanism for the action of insulin via oligopeptide mediator formation. Fed. Proc. 41: 2724-2729.

Layer, P. G., and E. M. Shooter (1983) Binding and degradation of nerve growth factor by PC12-pheochromocytoma cells. J. Biol. Chem. 258: 3012-3018.

Lucas, C. A., A. Czlonkowska, and G. W. Kreutzberg (1981) Regulation of acetylcholinesterase activity in the pheochromocytoma PC12 clonal nerve cell line by $\mathrm{C} 6$ glioma conditional medium and brain homogenates. Biol. Cell 41: 91-96.

Marchisio, P. C., L. Naldini, and P. Calissano (1980) Intracellular distribution of nerve growth factor in rat pheochromocytoma PC12 cells: Evidence for a perinuclear and intranuclear location. Proc. Natl. Acad. Sci. U. S. A. 77: 1656-1660.

Nasi, S., D. Cirillo, L. Naldini, P. C. Marchisio, and P. Calissano (1982) Microtubules and microfilaments in fixed and permeabilized cells are selectively decorated by nerve growth factor. Proc. Natl. Acad. Sci. U. S. A. 79: 820-824.

Naujoks, K. W., S. Korsching, H. Rohrer, and H. Thoenen (1982) Nerve growth factor-mediated induction of tyrosine hydroxylase and of outgrowth in cultures of bovine adrenal chromaffin cells: dependence on developmental stage. Dev. Biol. 92: 365-379.

Okada, C. Y., and M. Rechsteiner (1982) Introduction of macromolecules into cultured mammalian cells by osmotic lysis of pinocytic vesicles. Cell 29: 33-41.

Olsnes, S., C. Fernandez-Peuntes, L. Carrasco, and D. Vazques (1975) Ribosome inactivation by the toxin lectins abrin and ricin. Eur. J. Biochem. 60: 281-288.

Paine, P. L., L. C. Moore, and S. B. Horowitz (1975) Nuclear envelope permeability. Nature 254: 109-114.

Pappenheimer, A. M., Jr. (1977) Diphtheria toxin. Annu. Rev. Biochem. 46: 69-94.

Paravicini, U., K. Stoeckel, and H. Thoenen (1975) Biological importance of retrograde axonal transport of nerve growth factor in adrenergic neurons. Brain Res. 84: 279-291.

Puma, P., S. E. Buxser, L. Watson, D. J. Kelleher, and G. L. Johnson (1983) Purification of the receptor for nerve growth factor from A875 melanoma cells by affinity chromatography. J. Biol. Chem. 258: 3370-3375.

Rohrer, H., U. Otten, and H. 'Ihoenen (1978) On the role of RNA synthesis in the selective induction of tyrosine hydroxylase by nerve growth factor. Brain Res. 159: 436-439.

Rohrer, H., T. Schaefer, S. Korsching, and H. Thoenen (1982) Inter- 
nalization of nerve growth factor by pheochromocytoma PC12 cells: Absence of transfer to the nucleus. J. Neurosci. 2: 687-697.

Savion, N., I. Vlodavsky, and D. Gospodarowicz (1980) Role of the degradation process in the mitogenic effect of epidermal growth factor. Proc. Natl. Acad. Sci. U. S. A. 77: 1466-1470.

Schechter, Y., K. -J. Chang, S. Jacobs, and P. Cuatrecasas (1979a) Modulation of binding and bioactivity of insulin by anti-insulin antibody: Relation to possible role of receptor self-aggregation in hormone action. Proc. Natl. Acad. Sci. U. S. A. 76: 2720-2724.

Schechter, Y., L. Hernaez, J. Schlessinger, and P. Cuatrecasas (1979b) Local aggregation of hormone-receptor complexes is required for activation by epidermal growth factor. Nature $278: 835-838$.

Schlegel, R. A., and W. E. Mercer (1980) Red cell mediated microinjection of quiescent fibroblasts. In Introduction of Macromolecules into Viable Mammalian Cells, R. Baserga, C. Croce, and G. Rovera, eds., pp. 145-155, Alan R. Liss, Inc., New Yurk.

Schreiber, A. B., T. A. Libermann, I. Lax, Y. Yarden, and J. Schlessinger (1983) Biological role of epidermal growth factor-receptor clustering. J. Biol. Chem. 258: 846-853.

Schwab, M. E. (1977) Ultrastructural localization of a nerve growth factor-horseradish peroxidase (NGF-HRP)-coupling product after retrograde axonal transport in adrenergic neurons. Brain Res. 130: 190-196.

Schwab, M. E., and H. Thoenen (1977) Selective transsynaptic migration of tetanus toxin after retrograde axonal transport in peripheral sympathetic nerves: A comparison with nerve growth factor. Brain Res. 122: 459-474.

Seals, J. R., and M. P. Czech (1982) Production by plasma membranes of a chemical mediator of insulin action. Fed. Proc. 41: 2730-2735.

Seeley, P. J., and L. A. Greene (1983) Short-latency local actions of nerve growth factor at the growth cone. Proc. Natl. Acad. Sci. U. S. A. 80: 2789-2793.

Seeley, P. J., C. H. Keith, M. L. Shelanski, and L. A. Greene (1983) Pressure microinjection of nerve growth factor and anti-nerve growth factor into the nucleus and cytoplasm: Lack of effects on neurite outgrowth from pheochromocytoma cells. J. Neurosci. 3: 1488-1494.

Shooter, E. M., B. A. Yankner, G. E. Landreth, and A. Sutter (1981) Biosynthesis and mechanism of action of nerve growth factor. Recent Prog. Horm. Res. 37: 417-446.

Stoeckel, K., M. Schwab, and H. Thoenen (1975) Specificity of retrograde transport of nerve growth factor (NGF) in sensory neurons: $A$ biochemical and morphological study. Brain Res. 89: 1-14.

Stoeckel, K., C. Gagnon, G. Guroff, and H. Thoenen (1976) Purification of nerve growth factor antibodies by affinity chromatography. J. Neurochem. 26: 1207-1211.

Suda, K., Y. -A. Barde, and H. Thoenen (1978) Nerve growth factor in mouse and rat serum: Correlation between bioassay and radioimmunoassay determinations. Proc. Natl. Acad. Sci. U. S. A. 75: 40424046.

Sutter, A., R. J. Riopelle, R. M. Harris-Warrick, and F. M. Shooter (1979) Nerve growth factor receptors. J. Biol. Chem. 254: 5972-5982.

Tanaka, W. (1983) Absorption, distribution, metabolism, and excretion of leupeptin. In Proteinase Inhibitors, N. Katunuma, H. Umezawa, and H. Holzer, eds., pp. 17-24, Japan Scientific Society Press, Tokyo/ Springer-Verlag, Berlin.

Thoenen, H., and Y. -A. Barde (1980) Physiology of nerve growth factor. Physiol. Rev. 60: 1284-1335.

Willingham, M. C., H. T. Haigler, D. J. P. Fitzgerald, M. G. Gallo, A. V. Rutherford, and I. H. Pastan (1983) The morphologic pathway of binding and internalization of epidermal growth factor in cultured cells. Exp. Cell Res. 146: 163-175.

Yamaizumi, M., E. Mekada, T. Uchida, and Y. Okada (1978) One molecule of diphtheria toxin fragment $\mathrm{A}$ introduced into a cell can kill the cell. Cell 15: 245-250.

Yamaizumi, M., T. Uchida, E. Mekada, Y. Okada (1979) Antibodies introduced into living cells by red cell ghosts are functionally stable in the cytoplasm of the cells. Cell 18: 1009-1014.

Yankner, B. A., and E. M. Shooter (1982) The biology and mechanism of action of nerve growth factor. Annu. Rev. Biochem. 51: 845-868. 